\title{
Identification of runoff generation processes using hydrometric and tracer methods in a meso-scale catchment in Rwanda
}

\author{
O. Munyaneza $^{1,2}$, J. Wenninger ${ }^{2,3}$, and S. Uhlenbrook ${ }^{2,3}$ \\ ${ }^{1}$ Department of Civil Engineering, National University of Rwanda, P.O. Box 117, Butare, Rwanda \\ ${ }^{2}$ Department of Water Science and Engineering, UNESCO-IHE Institute for Water Education, P.O. Box 3015, \\ 2601 DA Delft, The Netherlands \\ ${ }^{3}$ Section of Water Resources, Delft University of Technology, P.O. Box 5048, 2600 GA Delft, The Netherlands
}

Correspondence to: O. Munyaneza (munyoma2000@yahoo.fr, o.munyaneza@unesco-ihe.org)

Received: 6 December 2011 - Published in Hydrol. Earth Syst. Sci. Discuss.: 12 January 2012

Revised: 4 June 2012 - Accepted: 6 June 2012 - Published: 9 July 2012

\begin{abstract}
Understanding of dominant runoff generation processes in the meso-scale Migina catchment $\left(257.4 \mathrm{~km}^{2}\right)$ in southern Rwanda was improved using analysis of hydrometric data and tracer methods. The paper examines the use of hydrochemical and isotope parameters for separating streamflow into different runoff components by investigating two flood events which occurred during the rainy season "Itumba" (March-May) over a period of $2 \mathrm{yr}$ at two gauging stations. Dissolved silica $\left(\mathrm{SiO}_{2}\right)$, electrical conductivity (EC), deuterium $\left({ }^{2} \mathrm{H}\right)$, oxygen-18 $\left({ }^{18} \mathrm{O}\right)$, major anions $\left(\mathrm{Cl}^{-}\right.$and $\left.\mathrm{SO}_{4}^{2-}\right)$ and major cations $\left(\mathrm{Na}^{+}, \mathrm{K}^{+}, \mathrm{Mg}^{2+}\right.$ and $\mathrm{Ca}^{2+}$ ) were analyzed during the events. ${ }^{2} \mathrm{H},{ }^{18} \mathrm{O}_{,} \mathrm{Cl}^{-}$and $\mathrm{SiO}_{2}$ were finally selected to assess the different contributing sources using mass balance equations and end member mixing analysis for two- and three-component hydrograph separation models. The results obtained by applying two-component hydrograph separations using dissolved silica and chloride as tracers are generally in line with the results of three-component separations using dissolved silica and deuterium. Subsurface runoff is dominating the total discharge during flood events. More than $80 \%$ of the discharge was generated by subsurface runoff for both events. This is supported by observations of shallow groundwater responses in the catchment (depth $0.2-2 \mathrm{~m}$ ), which show fast infiltration of rainfall water during events. Consequently, shallow groundwater contributes to subsurface stormflow and baseflow generation. This dominance of subsurface contributions is also in line with the observed low runoff coefficient values (16.7 and $44.5 \%$ ) for both events. Groundwater recharge during the wet seasons leads to a perennial river system. These
\end{abstract}

results are essential for better water resources planning and management in the region, which is characterized by very highly competing demands (domestic vs. agricultural vs. industrial uses).

\section{Introduction}

Understanding of runoff components separation processes is essential for the proper assessment of water resources availability within catchments. The use of environmental isotopes in combination with hydrochemical tracers and hydrometric measurements can help to gain further insights into hydrological processes because the methods separate and quantify different runoff components during rainfall events. Combined methods can be used to quantify the contributions of runoff components during different hydrological situations (floods and low flows) in small and meso-scale catchments (Didszun and Uhlenbrook, 2008; Wenninger et al., 2008). Generally, hydrochemical and isotopic hydrograph separations of stream discharge are commonly used to determine the fractions of surface/subsurface or old/new water contributions to streamflow (e.g. Richey et al., 1998).

Most hydrograph separations involve the standard twocomponent mixing models of Sklash and Farvolden (1979), in which the stream water is separated into old (pre-event) and new (event) water components. This approach identifies the age of streamflow components, but cannot be used to assess the spatial origin (Ladouche et al., 2001). To obtain both temporal and spatial origins, some investigations using stable 
isotopes associated with chemical tracers have been undertaken in different basins world-wide (for example, Kennedy et al., 1986; Wels et al., 1991; Ladouche et al., 2001; Uhlenbrook and Hoeg, 2003; Hrachowitz et al., 2011). However, hydrochemical tracers may only be used to separate streamflow into runoff components according to their flow paths (Kennedy et al., 1986).

Only a few recent studies on the application of two and three-component hydrograph separation models improved our understanding of hydrological processes in semi-arid areas in Sub-Sahara Africa (Mul et al., 2008; Hrachowitz et al., 2011), where Rwanda is also located. These studies contribute to appropriately manage the available surface water and groundwater resources, both in terms of quality and quantity. This is essential in Rwanda where the population is growing with an annual rate of about $3.5 \%$ (MINIPLAN, 2002), and it is already the most densely populated country on the African continent (NELSAP, 2007). The related increase of water demand for domestic, agricultural, and industrial uses is causing significant water scarcity in the country, and ecosystems are under enormous pressure.

Burns (2002) put it nicely by stating: "As the science matured further in the 1990s, a point was reached at which isotope-based hydrograph separations alone were insufficient to guarantee publication of study results in the leading water resources journals. Many studies seemed only to reconfirm that stormflow in small forested catchments is dominated by "pre-event" or "old" water, and hydrologists did not need to be told so over and over again. Thus, isotopebased hydrograph separation had become simply another tool - one that could not lead to a more profound understanding of catchment runoff processes unless combined with many other tools." Since then, the application of hydrograph separation together with hydrometric observation became state of the art in the global North, but much less in the global South, in particular in remote area of Africa with its unique hydro-climatic and other physiographic settings. However, hydrograph separation methods were applied before to semiarid or better sub-humid catchments with the support of well data (Cras et al., 2007; Marc et al., 2011; Hrachowitz et al. 2011), but these study sites are different than the study area in Rwanda.

Detailed insights into the hydrology of a meso-scale catchment like the Migina catchment contributes to an increased understanding regarding the water resources of the catchment - an important first step in protecting ecosystems and existing users and ensuring a sustainable level of development in the future. This knowledge can help farmers to increase their crop production and to sustain long-term food security (e.g. Mul, 2009; Hrachowitz et al., 2011). In order to achieve this, insights into the behavior of the water fluxes and the interactions between groundwater and surface water is of utmost importance. Munyaneza et al. (2011) conducted their study in the meso-scale Migina catchment, southern Rwanda, to predict river flows. Van den Berg and Bolt (2010) also conducted their research in the same catchment using hydrochemical and isotope analysis during the dry season. Based on a baseflow recession curve analysis, they showed a decreasing trend in baseflow in the overall river discharge. It is now becoming almost constant at a rate of $0.19 \mathrm{~m}^{3} \mathrm{~s}^{-1}$ at the main outlet at the end of the dry season. Furthermore, they concluded that a significant flow from (deep) groundwater has to be the source of this water. Hence, the suggestion was made to perform detailed hydrochemical and isotopic hydrograph investigations also during floods to obtain a better understanding of groundwater-surface water interactions as well as the different sources and flow pathways. Burns (2002) found that the thrill of doing isotope-based hydrograph separations in forested, humid catchments is gone. Therefore, he recommended carrying out new studies in catchments with different climatic and human disturbance regimes. Additionally, these studies which combine water-isotope and solute isotope measurements should provide hydrologists with new thrills and even surprises in the coming years. Consequently, the current study was carried out in a semi-arid catchment and contributes to the advancement of hydrologic science of this hydro-climatic zone by quantifying runoff components and processes. Hardly any studies can be found in related hydro-climatic zones in the literature; therefore, we feel this study is a good addition to the existing knowledge base.

The objective of the paper is to quantify the runoff components and to identify the dominant processes in a mesoscale catchment for two flood events occurred during the rainy season "Itumba" (March-May) over a period of $2 \mathrm{yr}$, i.e. 1 to 2 May 2010 at Kansi sub-catchment and 29 April to 6 May 2011 at Migina catchment in southern Rwanda (Fig. 1). Specifically, the study emphasizes the use of twoand three-component hydrograph separation mixing models for separating streamflow into surface and subsurface runoff and quantifies different runoff components under tropical conditions. In order to learn more about hydrologic flow paths, hydrochemical tracers and hydrometric measurements such as rainfall, stream discharge, springs and groundwater levels were combined with tracer studies. The study explores the importance of combining hydrometric data, isotope information and hydrochemical tracers to identify runoff components (e.g. Ladouche et al., 2001; Uhlenbrook et al., 2002).

\section{Study area}

The study was carried out in the meso-scale Migina catchment $\left(257.4 \mathrm{~km}^{2}\right)$ and in the Kansi sub-catchment $\left(129.3 \mathrm{~km}^{2}\right)$, which are located in southern Rwanda (Fig. 1). Approximately 103000 inhabitants with an annual growth rate of about $3 \%$ are living in the Migina catchment (Nahayo et al., 2010; Van den Berg and Bolt, 2010). The geology of the Migina catchment consists of very old granite rocks, overlain by substrates of grey quartzites and schists. These geological differences result in differences in 


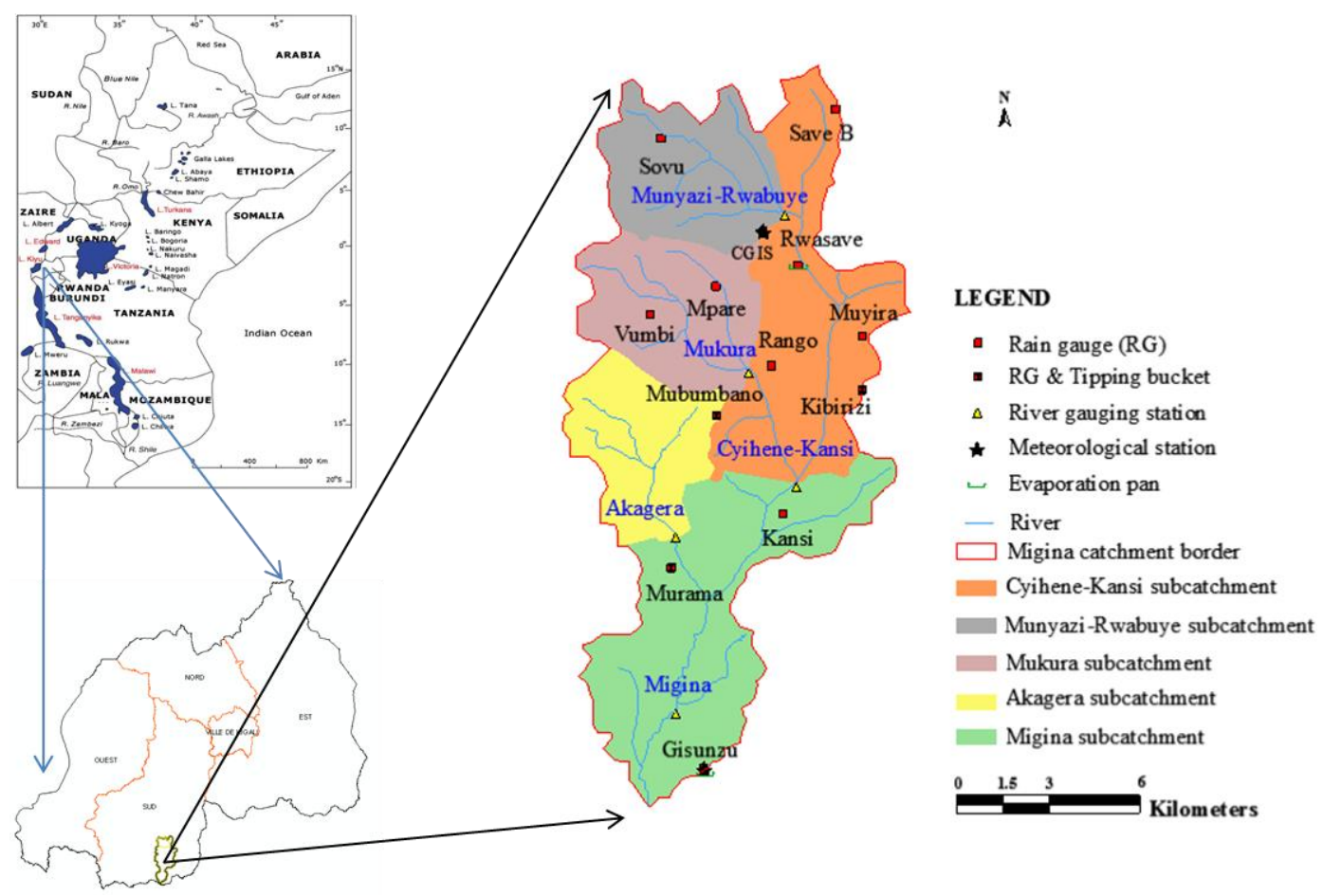

Fig. 1. Location of the Migina catchment in Rwanda and East Africa, and instrumentation set-up within this research project showing the positions of Kansi and Migina gauging stations.

topography. The site is mountainous with elevations ranging from $1375 \mathrm{~m}$ a.s.l. at the outlet to $2278 \mathrm{~m}$ a.s.l. at Mount Huye, which is located in the north-western part of the catchment. The topographic conditions are very variable and slopes of the valleys vary from 5 to $10 \%$ in the upstream and 1 to $15 \%$ in the downstream part (average slope is between 2 and $3 \%$ ) (see Nahayo et al., 2010). The soils in the valleys are often ferrallitic with a $50 \mathrm{~cm}$ thick humic Ahorizon, which are sometimes buried below dynamically colluviating deposits (Van den Berg and Bolt, 2010). The clay content of the A-horizon varies between $12 \%$ and $19 \%$ with hydraulic conductivities estimated between 1 and $10 \mathrm{md}^{-1}$ (Moeyersons, 1991). Land cover and hydrological soil group analyses in the Migina catchment show that the catchment is dominated by agriculture activities $(92.5 \%)$, while forest occupy $5 \%$, grass/lawn $2 \%$ and buildings cover $0.5 \%$ (Munyaneza et al., 2011). This indicates that most of the water in the Migina catchment is used for agricultural purposes (irrigation) because all of these activities take place in the valleys close to the rivers.

The investigated catchments in this paper are: CyiheneKansi catchment, further called Kansi sub-catchment $\left(129.3 \mathrm{~km}^{2}\right)$; and Migina catchment $\left(257.4 \mathrm{~km}^{2}\right)$ which covers the whole catchment, including Kansi sub-catchment (see Fig. 1). The perennial Migina River drains into the Akanyaru River, which forms the border between Rwanda and Burundi. The Akanyaru River drains into the Kagera River, which flows into Lake Victoria and later generates the White Nile.

The mean annual rainfall in the Migina catchment is approximately $1200 \mathrm{~mm} \mathrm{yr}^{-1}$ and the mean annual temperature is about $20^{\circ} \mathrm{C}$ (S. H. E. R., 2003). The annual average evaporation in the area is estimated to $917 \mathrm{~mm} \mathrm{yr}^{-1}$ (Nahayo, 2008). The potential evaporation is much higher and was estimated to $605 \mathrm{~mm} \mathrm{yr}^{-1}$. The Migina catchment has a moderate climate with relatively high rainfall and an annual cycle of two rainy seasons (FAO, 2005): (1) A short rainy season, locally known as "Umuhindo", lasts from September to November, with November characterized by heavy rainfall; this season is followed by a short dry season, locally known as "Urugaryi", lasts from December to February. (2) A long rainy season, locally known as "Itumba", lasts from March to May. This accounts for about $61 \%$ of the total annual rainfall. The investigated events occurred during the Itumba season (March to May) for the years 2010 and 2011.

\section{Data and methods}

\subsection{Data collection}

The catchment has been equipped with hydrological instruments (Fig. 1), and after installation, hydrochemical and isotope data were collected over two years (May 2009 to June 2011). Two events were examined in further detail 
during the long rainy season "Itumba". Intensive monitoring (hourly samples) was carried out between 1 and 2 May 2010 and between 29 April 2011 and 6 May 2011 at Kansi and Migina gauging stations, respectively. Samples were analyzed in the lab for isotopes and hydrochemical tracers. The collected samples include groundwater from 11 shallow piezometers, 15 springs, river discharge measurements from 5 river gauging stations (Rwabuye, Mukura, Kansi, Akagera, and Migina); stream water sampled is from 8 sites in the catchment (weekly or monthly intervals), and monthly catchment rainfall is from 5 locations where tipping buckets are installed (see Fig. 1). One rainfall event during the Itumba'11 season (from 29 April 2011 to 6 May 2011) was also sampled at Gisunzu rain gauge for isotopic composition analysis.

\subsection{Field and laboratory methods}

In-situ measurements have been continuously conducted at the outlet of each sub-catchment for $\mathrm{pH}$ value and water temperature $(T)$ using a portable $\mathrm{pH}$-meter (Hach 157), and for electrical conductivity (EC) using a Hanna Gro'Chek Portable EC-meter (HI9813-0). Stream, spring and rainwater samples were collected in $30 \mathrm{ml}$ plastic bottles. Samples were collected during low flows and flood events.

Samples were analyzed in the laboratory for dissolved silica $\left(\mathrm{SiO}_{2}\right)$ using a spectrophotometer DR 2400 at the laboratory of Kadahokwa water treatment plant and at the laboratory of the National University of Rwanda (NUR), Butare, Rwanda. The concentrations of major cations like $\mathrm{Mg}^{2+}$, $\mathrm{Ca}^{2+}$ and $\mathrm{K}^{+}$were determined by atomic absorption spectroscopy (AAS) at NUR, and sodium $\left(\mathrm{Na}^{+}\right)$was determined by AAS at UNESCO-IHE, Delft, The Netherlands. The concentrations of major anions like $\mathrm{SO}_{4}^{2-}$ were determined using a Hach-DR/890 colorimeter in the lab of WREM at NUR, and $\mathrm{Cl}^{-}$was analyzed by using an ion chromatograph at UNESCO-IHE and verified by using colorimetry in the lab of NUR. The isotopes were analyzed at UNESCO-IHE with a LGR liquid-water isotope analyzer, which provides measurements of $\delta^{18} \mathrm{O}$ and $\delta^{2} \mathrm{H}$ in liquid-water samples with accuracy better than $0.2 \%$ for ${ }^{18} \mathrm{O} /{ }^{16} \mathrm{O}$ and better than $0.6 \%$ for ${ }^{2} \mathrm{H} /{ }^{1} \mathrm{H}$.

During the investigated two flood events, the water levels were measured continuously at two river gauging stations (Kansi and Migina) using automatic recorders (Mini-Diver; DI501) and transferred to discharges using rating curves $\left(r^{2}=0.94, n=24\right.$ at Kansi station and $r^{2}=0.97, n=18$ at Migina station).

\subsection{Hydrometric and tracer methods}

Hydrograph separation to separate the runoff during floods in two or more components (end-members), based on the mass balances for tracer fluxes and water, was applied in this study. Environmental isotopes (oxygen-18 $\left({ }^{18} \mathrm{O}\right)$ and deuterium $\left.\left({ }^{2} \mathrm{H}\right)\right)$, dissolved silica $\left(\mathrm{SiO}_{2}\right)$ and chloride $\left(\mathrm{Cl}^{-}\right)$ were selected as tracers.

The fundamentals and assumptions of the hydrograph separation method are further discussed in, e.g. Sklash and Farvolden (1979), Wels et al. (1991), Buttle (1994) and Uhlenbrook and Hoeg (2003). The mass balance expression for a two-component hydrograph separation model used in this paper is described as follows:

$$
\begin{aligned}
Q_{\mathrm{t}} & =Q_{1}+Q_{2} \\
c_{\mathrm{t}} Q_{\mathrm{t}} & =c_{1} Q_{1}+c_{2} Q_{2},
\end{aligned}
$$

where $Q_{\mathrm{t}}$ is the total runoff $\left(\mathrm{m}^{3} \mathrm{~s}^{-1}\right) ; Q_{1}, Q_{2}$ are runoff contributions $\left(\mathrm{m}^{3} \mathrm{~s}^{-1}\right) ; c_{\mathrm{t}}$ is the concentration in the total $\left(\mathrm{mg} \mathrm{l}^{-1}\right.$ or $\% o$ ); and $c_{1}, c_{2}$ are the end-member concentrations of the tracers in the respective runoff component $\left(\mathrm{mg} \mathrm{l}^{-1}\right)$ or $(\% o)$.

The exact definition of the two or three runoff components depends on the properties of the tracer used (Wels et al., 1991). Two commonly used groups of tracers are: (1) stable isotopes of water, oxygen-18 $\left({ }^{18} \mathrm{O}\right)$ and deuterium $\left({ }^{2} \mathrm{H}\right)$ (e.g. Sklash and Farvolden, 1979; Sklash et al., 1986); and (2) weathering products such as $\mathrm{Mg}^{2+}, \mathrm{Ca}^{2+}, \mathrm{Cl}^{-}$and $\mathrm{SiO}_{2}$ (e.g. Pinder and Jones, 1969; Wels et al., 1991).

With a known concentration of the end-members for subsurface and surface runoff, the contribution from these sources can be calculated (e.g. Mul et al., 2008). The concentration for sub-surface (including groundwater) runoff was assumed to be the concentration of the pre-event water at the sampling point, and the concentration of the surface runoff was assumed to be similar to concentrations observed in a rainfall sample (Buttle, 1994; Mul et al., 2008). Therefore, the total discharge $Q_{\mathrm{t}}$ and concentrations $c_{\mathrm{t}}, c_{1}$ and $c_{2}$ are known and it follows:

$$
\begin{aligned}
& Q_{2}=\frac{c_{\mathrm{t}}-c_{1}}{c_{2}-c_{1}} Q_{\mathrm{t}} \\
& Q_{1}=Q_{T}-Q_{2} .
\end{aligned}
$$

Hrachowitz et al. (2011) applied hydrochemical tracers in combination with isotopic tracers for hydrograph separation in a semi-arid catchment in Tanzania. They found that the assumption of stable isotopic end-members was not met for both the groundwater samples and the rainwater samples. At the small scale the spatial variability could be negligible and the technique becomes better applicable, although for each event, end-member concentrations needed to be determined separately to account for the temporal variability. Due to this temporal variation, hydrograph separation was performed in this paper using the cumulative incremental weighting approach, Eq. (5), based on sampled rainfall amount as recommended by McDonnell et al. (1990):

$\delta^{18} \mathrm{O}=\frac{\sum_{i=1}^{n} P_{i} \delta_{i}}{\sum_{i=1}^{n} P_{i}}$, 
where $P_{i}$ and $\delta_{i}$ denote fractionally collected rainfall amounts and $\delta$ values (isotope concentrations), respectively. The weighted mean represents the average isotopic composition of the event water input to the catchment but does not address the within-storm isotopic variability or the time response of the catchment to event water (McDonnell et al., 1990).

A three-component hydrograph separation was applied in this study by using dissolved silica and deuterium for the event of 1-2 May 2010 at Kansi station (Fig. 7) and using dissolved silica and oxygen-18 as tracers for the event of 29 April 2011 to 6 May 2011 at Migina station (Fig. 9). The same method was used by James and Roulet (2009) to estimate the relative contributions of throughfall, a perched groundwater or shallow subsurface flow component, and groundwater for individual storm events in small forest catchments of Mont Saint-Hilaire in Quebec, Canada. During our research, three end-members (pre-event: deep and shallow groundwater, and event: rainfall) were used in the separation. End-member concentrations were collected for each event separately in order to account as good as possible for the temporal variability. The end-member for deep groundwater was selected to be the one from springs and from deep piezometers installed in hillslope. Shallow piezometers close to stream were considered to represent the end member of shallow groundwater. The end-member concentration for rainfall was taken as average rainwater sampled at four automatic (tipping buckets) rainfall stations installed in the study area (see Fig. 1).

Event-based runoff coefficient estimations were determined from Thiessen polygon representation of rainfall and continuous runoff records (Burch et al., 1987; Iroumé et al., 2005; Blume et al., 2007). In the study presented here, the runoff coefficient for each event was computed by dividing the total flow by the total rainfall as recommended by Spieksma (1999) and Iroumé et al. (2005). Using total flow allows us to combine the response of the single event with the pre-event flow conditions (Blume et al., 2007). Rainfall measurements have been carried out by using 13 manual rain gauges installed in the Migina catchment. The endpoint of each event has been estimated by waiting until the discharge is back to baseflow conditions. This did not cause very long tailings (recession limbs) for the event, due probably to the short catchment response of $3 \mathrm{~h} 26 \mathrm{~min}$ observed by Munyaneza et al. (2011) in the same catchment.

\section{Results}

\subsection{Rainfall-runoff observations for Itumba'10 and 11 seasons (March-May)}

The observed discharges in the center of the Migina catchment at Kansi station, for data recorded from 1 May 2009 to 31 June 2011 , were in the range of $0.24-9.16 \mathrm{~m}^{3} \mathrm{~s}^{-1}$

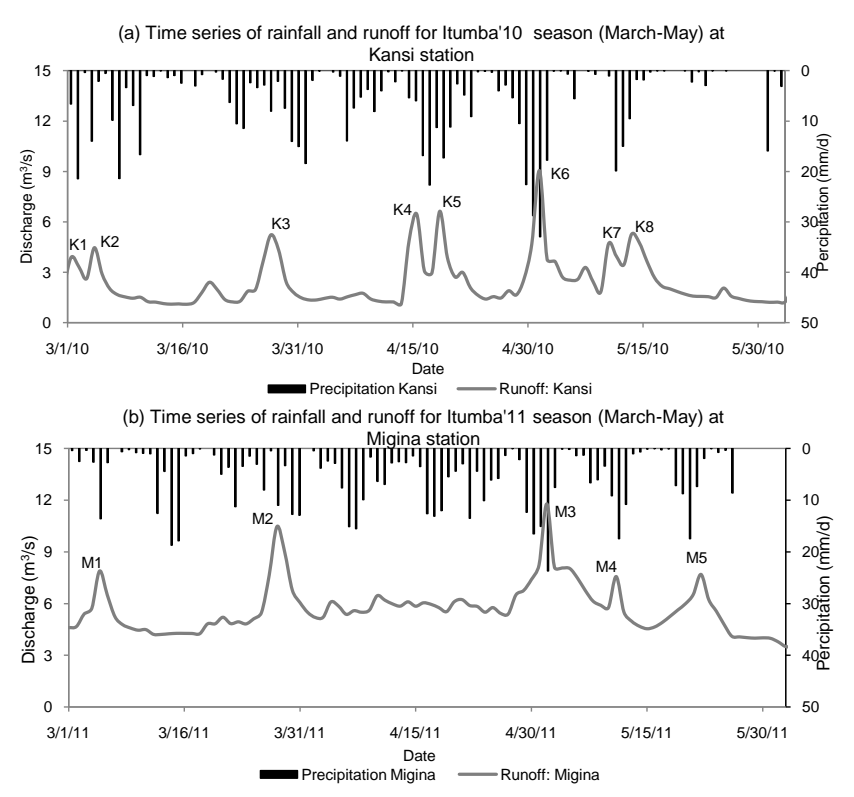

Fig. 2. Time series of rainfall and runoff events during MarchMay 2010 at Kansi station (a) and March-May 2011 at Migina station (b).

and average discharge was estimated to $1.71 \mathrm{~m}^{3} \mathrm{~s}^{-1}$. The observed discharges at the outlet of Migina catchment (at Migina station), for data recorded from 1 August 2009 to 31 June 2011 , were in the range of $0.43-15.60 \mathrm{~m}^{3} \mathrm{~s}^{-1}$ with an average discharge of $3.35 \mathrm{~m}^{3} \mathrm{~s}^{-1}$.

Rainfall measurements have been done at 13 manual rain gauges installed in the Migina catchment, i.e. the Gisunzu and Murama rain stations were not considered for the areal rainfall of the Kansi sub-catchment (see Fig. 1). The amount of rainfall in both Kansi and Migina catchments were estimated using the Thiessen polygons method, which seems appropriate due to spatial distribution of the rainfall stations and the low topographic gradients.

Figure 2 shows the rainfall and discharge patterns observed at Kansi (Fig. 2a) and Migina (Fig. 2b) gauging stations during the investigated periods (Itumba' 10 and Itumba'11). The in-detail investigated two flood events are event K6 for Kansi station and event M3 for Migina station (Tables 1 and 2). Seasonal rainfall totals to $552 \mathrm{~mm}$ and $508 \mathrm{~mm}$ for Kansi sub-catchment and Migina catchment, respectively. These seasonal rainfall totals generate, on average, a runoff of $2.42 \mathrm{~m}^{3} \mathrm{~s}^{-1}(148.7 \mathrm{~mm})$ at Kansi station, and $5.75 \mathrm{~m}^{3} \mathrm{~s}^{-1}(177.7 \mathrm{~mm})$ at Migina station.

The time series of rainfall and runoff for storm event K6 and $\mathrm{M} 3$ represent the intensive monitoring periods in this research. Maximum daily rainfall of $32.9 \mathrm{~mm} \mathrm{~d}^{-1}$ $\left(4.3 \times 10^{6} \mathrm{~m}^{3}\right)$ was observed on 2 May 2010 in Kansi sub-catchment and the runoff generated by this rainfall at Kansi station reaches its peak at the same day at 03:00 LT $\left(9.05 \mathrm{~m}^{3} \mathrm{~s}^{-1}\right)$. The river discharge returns to pre-event values on 5 May 2010 when the surface runoff contribution 
Table 1. Rainfall-runoff events during Itumba' 10 season in the Kansi sub-catchment $\left(129.3 \mathrm{~km}^{2}\right)$. The in-detail investigated event K6 is given in bold.

\begin{tabular}{|c|c|c|c|c|c|c|c|c|c|c|}
\hline Event No. & Date & Time & \multicolumn{2}{|c|}{ Rainfall event } & \multicolumn{3}{|c|}{ Runoff event } & $\begin{array}{c}\text { Runoff } \\
\text { volume } \\
\left(10^{4} \mathrm{~m}^{3}\right)\end{array}$ & $\begin{array}{r}\text { Total } \\
\text { Runoff } \\
(\mathrm{mm})\end{array}$ & $\begin{array}{c}\text { Runoff } \\
\text { coef. } \\
(\%)\end{array}$ \\
\hline $\mathrm{K} 1$ & 2 Mar & $07: 05$ & 8.0 & 2.0 & 41.98 & 3.91 & 0.109 & 119.5 & 9.24 & 22.0 \\
\hline $\mathrm{K} 2$ & $5 \mathrm{Mar}$ & $04: 20$ & 7.0 & 0.8 & 27.92 & 4.47 & 0.124 & 144.0 & 11.13 & 39.9 \\
\hline K3 & $28 \mathrm{Mar}$ & $10: 35$ & 7.0 & 5.6 & 70.09 & 5.23 & 0.146 & 229.9 & 17.78 & 25.4 \\
\hline K5 & 19 Apr & $10: 50$ & 11.3 & 9.2 & 79.51 & 6.63 & 0.185 & 293.5 & 22.70 & 28.5 \\
\hline K6 & 2 May & 03:00 & 22.0 & 16.6 & 113.27 & 9.05 & 0.252 & 265.0 & 20.49 & 18.1 \\
\hline K7 & 11 May & $23: 50$ & 5.5 & 10.6 & 47.12 & 4.69 & 0.131 & 120.6 & 9.32 & 19.9 \\
\hline K8 & 14 May & $18: 20$ & 6.0 & 3.6 & 50.57 & 5.26 & 0.147 & 291.3 & 22.53 & 44.5 \\
\hline
\end{tabular}

Table 2. Rainfall-runoff events during Itumba' 11 season in the Migina catchment $\left(257.4 \mathrm{~km}^{2}\right)$. The in-detail investigated event M3 is given in bold.

\begin{tabular}{|c|c|c|c|c|c|c|c|c|c|c|}
\hline \multirow[b]{2}{*}{ Event No. } & \multirow[b]{2}{*}{ Date } & \multirow[b]{2}{*}{ Time } & \multicolumn{2}{|c|}{ Rainfall event } & \multicolumn{3}{|c|}{ Runoff event } & \multirow[b]{2}{*}{$\begin{array}{l}\text { Runoff } \\
\text { volume } \\
\left(10^{4} \mathrm{~m}^{3}\right)\end{array}$} & \multirow[b]{2}{*}{$\begin{array}{l}\text { Total } \\
\text { Runoff } \\
(\mathrm{mm})\end{array}$} & \multirow[b]{2}{*}{$\begin{array}{c}\text { Runoff } \\
\text { coef. } \\
(\%)\end{array}$} \\
\hline & & & $\begin{array}{r}\text { Duration } \\
\text { (h) }\end{array}$ & $\begin{array}{r}\text { Maximum } \\
\text { rainfall intensity } \\
\left(\mathrm{mm} \mathrm{h}^{-1}\right)\end{array}$ & $\begin{array}{l}\text { Rainfall } \\
\text { amount } \\
(\mathrm{mm})\end{array}$ & $\begin{array}{r}\text { Peak } \\
\text { runoff } \\
\left(\mathrm{m}^{3} \mathrm{~s}^{-1}\right)\end{array}$ & $\begin{array}{l}\text { Peak storm } \\
\text { runoff } \\
\left(\mathrm{mm} \mathrm{h}^{-1}\right)\end{array}$ & & & \\
\hline M1 & $5 \mathrm{Mar}$ & $09: 38$ & 11.0 & 12.0 & 75.87 & 7.89 & 0.110 & 615.8 & 23.92 & 31.5 \\
\hline M2 & $28 \mathrm{Mar}$ & 00:08 & 6.2 & 14.8 & 49.87 & 10.46 & 0.146 & 570.5 & 22.16 & 44.4 \\
\hline M3 & 2 May & 10:00 & 14.0 & 17.6 & 96.32 & 11.78 & 0.165 & 883.6 & 34.32 & 35.6 \\
\hline M4 & 11 May & $03: 51$ & 2.5 & 7.6 & 42.47 & 7.57 & 0.106 & 421.4 & 16.37 & 38.5 \\
\hline M5 & 22 May & $02: 20$ & 10.0 & 9.4 & 54.31 & 7.69 & 0.108 & 447.3 & 17.37 & 32.0 \\
\hline
\end{tabular}

stopped. Similarly, a maximum daily rainfall of $23.7 \mathrm{~mm} \mathrm{~d}^{-1}$ $\left(6.1 \times 10^{6} \mathrm{~m}^{3}\right)$ was observed on 2 May 2011 in the Migina catchment and the runoff generated by this rainfall at Migina station, reaches also at the same day its peak at 10:00 LT $\left(11.78 \mathrm{~m}^{3} \mathrm{~s}^{-1}\right)$. The river discharge returns to pre-event values on 6 May 2011.

Tables 1 and 2 show the main hydrological characteristics of 8 different events during Itumba' 10 and 5 different events monitored during Itumba'11 at Kansi and Migina gauging stations, respectively. Runoff coefficients were observed ranging from $16.7 \%$ to $44.5 \%$, with maximum rainfall intensities up to $16.6 \mathrm{~mm} \mathrm{~h}^{-1}$ for Itumba' 10 and $17.6 \mathrm{~mm} \mathrm{~h}^{-1}$ for Itumba' 11.

Most rain events during both seasons Itumba'10 and Itumba'11 are moderate $\left(2.5\right.$ to $\left.7.5 \mathrm{~mm} \mathrm{~h}^{-1}\right)$ or heavy $\left(>7.5 \mathrm{~mm} \mathrm{~h}^{-1}\right)$. Only light rain is observed on 2 March 2010 at 07:05 $\left(2.0 \mathrm{~mm} \mathrm{~h}^{-1}\right)$ and on 5 March 2010 at 04:20 $\left(0.8 \mathrm{~mm} \mathrm{~h}^{-1}\right)$ for the Itumba'10 season (Table 1$)$. The observed low runoff coefficients for Kansi sub-catchment (16.7-44.5\%) and Migina catchment (31.5-44.4\%) indicate that a high percentage of the rainfall becomes subsurface runoff. This is later proven by the hydrograph separation (see Sect. 4.3). Rainfall amount and runoff volume show a strong correlation ( $r=0.93, n=18)$ for Kansi sub-catchment and $(r=0.95, n=19)$ for Migina catchment.

\subsection{Results of hydrochemical tracer studies}

The most important hydro-chemical parameters of the water samples from springs, rivers, rainfall and shallow groundwater wells are presented in Table 3.

Table 3 shows that the concentrations of most of the chemical components in surface water are related to the concentrations of water sampled from springs and piezometers during flood events. Only the opposite can be seen in dissolved silica $\left(\mathrm{SiO}_{2}\right)$ and electrical conductivity (EC) concentrations. This indicates that surface discharge is dominated by subsurface runoff components during flood events in the Migina catchment. This agrees with the low runoff coefficients observed in the catchments (Tables 1 and 2).

Figure 3 shows the concentrations of dissolved silica and chloride during the two investigated events. The hydrograph is rising from $2.6 \mathrm{~m}^{3} \mathrm{~s}^{-1}$ to $9.1 \mathrm{~m}^{3} \mathrm{~s}^{-1}$ at Kansi River and from $6.5 \mathrm{~m}^{3} \mathrm{~s}^{-1}$ to $11.8 \mathrm{~m}^{3} \mathrm{~s}^{-1}$ at the outlet of Migina catchment. Unfortunately, baseflow was not sampled for the season Itumba'10 (Fig. 3a) but sampled for season Itumba'11 (Fig. 3b). 

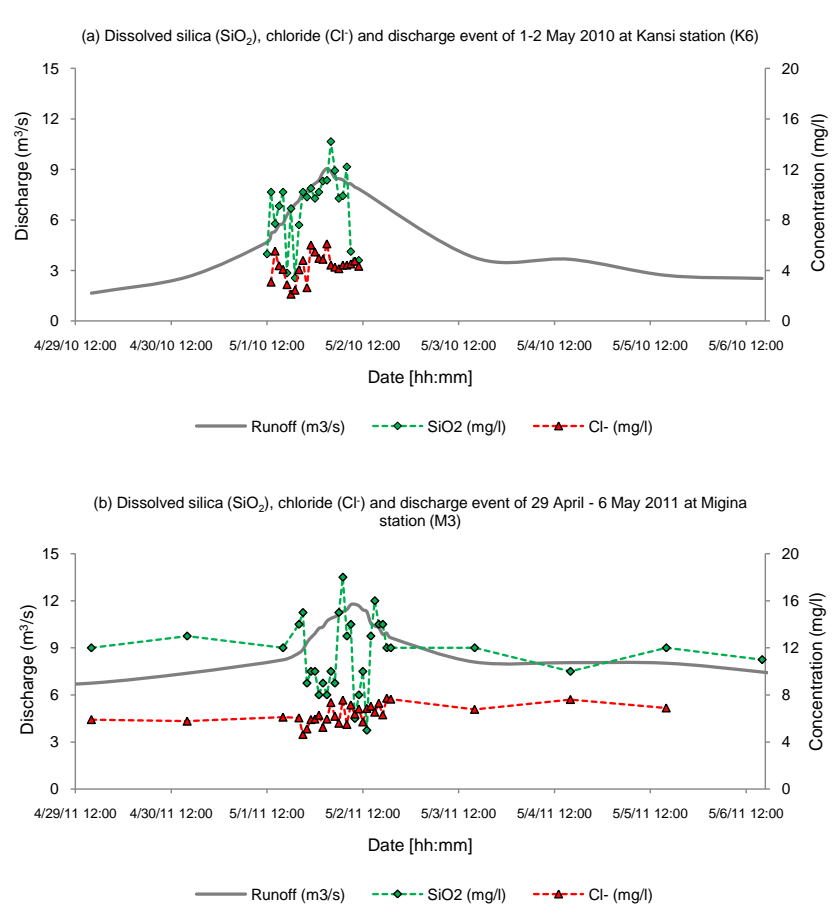

Fig. 3. Hydrochemical parameter responses at Kansi station during 1-2 May 2010 storm event (a) and at Migina station during 29 April to 6 May 2011 storm event (b).

Hourly $\mathrm{SiO}_{2}$ and $\mathrm{Cl}^{-}$concentrations observed in stream water during the event of 1 to 2 May 2010 do not show clear trends, but a small increase was observed during the peak flow that was followed by constant concentrations for $\mathrm{Cl}^{-}$and smooth recession towards background concentration for $\mathrm{SiO}_{2}$ (Fig. 3a). The observed concentrations during low flows for season Itumba'11 do not present clear trends as well but increase and decrease near the peak can be seen during the flood event (Fig. 3b). This means that the hydrochemical parameters $\left(\mathrm{SiO}_{2}\right.$ and $\left.\mathrm{Cl}^{-}\right)$show a similar behavior for this event; remain constant during low flows, between $10-12 \mathrm{mg}^{-1}$ for $\mathrm{SiO}_{2}$ and 5.8-7.6 $\mathrm{mg} \mathrm{l}^{-1}$ for $\mathrm{Cl}^{-}$; and distinct variations were observed during flood events, between 4-18 $\mathrm{mg} \mathrm{l}^{-1}$ for $\mathrm{SiO}_{2}$ and 4.6-7.7 $\mathrm{mg} \mathrm{l}^{-1}$ for $\mathrm{Cl}^{-}$(Fig. 3b).

Figure 4 demonstrates that hydrograph separations using dissolved silica (Fig. 4a) and chloride (Fig. 4b) as tracers show that subsurface runoff during the event on 2 May 2010 is dominating the surface runoff and contributes from 54 to $89 \%$ (about $75 \%$ on average) and from 50 to $85 \%$ (about $70 \%$ on average), respectively. This confirms the observation of low contribution of direct surface runoff, supported by low runoff coefficients (Tables 1 and 2). Due to the fact that the whole rising limb, peak and recession limb were not captured completely for this event, the entire streamflow generated by groundwater could not be quantified. However, the dominance of subsurface runoff was observed during the starting time of the event sampling and subsurface runoff contributed $77.2 \%$, which allows concluding that the overall contribution
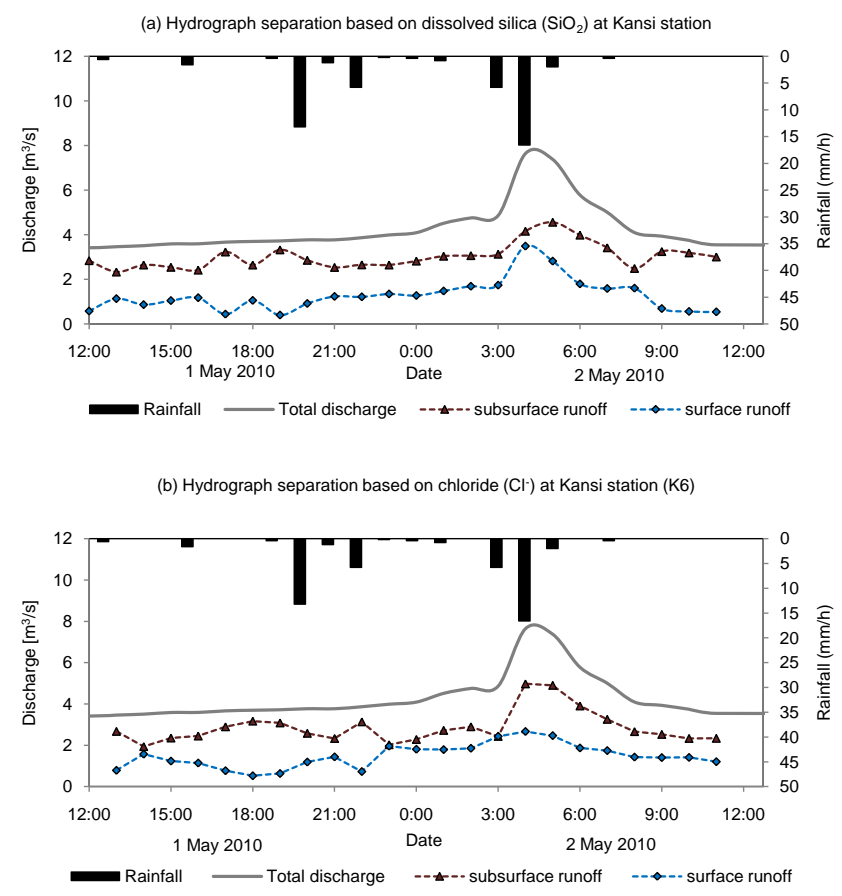

Fig. 4. Results of two-component hydrograph separations based on dissolved silica (a) and chloride (b) for subsurface and surface runoff for event K6 (see Fig. 2a) investigated from 1 May 2010 at 12:00 to 2 May 2010 at 11:00 at Kansi station.

of surface runoff is relative small. The fact that surface runoff could be detected even before the main event is due to rainfall distribution during the rainy season that triggered some localized surface runoff generation and (delayed) inflow to the river throughout the season.

The observed maximum contributions of surface runoff during the peak flows are not equal in terms of timing for the separations using dissolved silica $\left(\mathrm{SiO}_{2}\right)$ and chloride $\left(\mathrm{Cl}^{-}\right)$. Using $\mathrm{SiO}_{2}$ the maximum surface runoff contribution $(45 \%)$ was observed on 2 May 2010 at 15:00 LT, then one hour later the peak runoff was reached at 16:00 LT while using $\mathrm{Cl}^{-}$; about $50 \%$ of this contribution was observed at the same time as the peak runoff (on 2 May 2010 at 15:00 LT). This timing difference can be attributed to various uncertainties related to the method (cf. methods section) and should not be over-interpreted. The observed subsurface runoff dominance is also supported by the findings of Munyaneza et al. (2011) who showed that groundwater in the Migina catchment is very shallow (depth between $0.2-2 \mathrm{~m}$ in the valleys) and infiltrated rainwater can reach the groundwater quickly and contribute to subsurface stormflow and baseflow during and after events, respectively. The depth can reach up to $4.1 \mathrm{~m}$ at the hilltops, as found by Van den Berg and Bolt (2010).

Figure 5 shows the hydrograph separations using dissolved silica (Fig. 5a) and chloride (Fig. 5b) as tracers during the event of 29 April 2011 to 6 May 2011 at Migina station. The results are similar to the separations for event of 
Table 3. Hydrochemical concentrations observed in the Kansi sub-catchment and Migina catchment during the investigated research period (from 1 May 2009 to 31 June 2011). $n$ represents the number of samples. The entries in brackets represent the standard deviation values.

\begin{tabular}{|c|c|c|c|c|c|c|c|c|c|c|}
\hline & \multirow[b]{2}{*}{ Parameter } & \multirow[b]{2}{*}{ Unit } & \multicolumn{2}{|c|}{$\begin{array}{l}\text { Rainfall } \\
(n=103)\end{array}$} & \multicolumn{2}{|c|}{$\begin{array}{l}\text { Surface water } \\
\quad(n=173)\end{array}$} & \multicolumn{2}{|c|}{$\begin{array}{l}\text { Groundwater } \\
\quad(n=59)\end{array}$} & \multicolumn{2}{|c|}{$\begin{array}{l}\text { Springs } \\
(n=34)\end{array}$} \\
\hline & & & Kansi & Migina & Kansi & Migina & Kansi & Migina & Kansi & Migina \\
\hline & \multirow[t]{2}{*}{$\mathrm{pH}$} & \multirow[t]{2}{*}{-} & 6.0 & 6.1 & 6.9 & 6.8 & 6.0 & 6.0 & 5.0 & 5.1 \\
\hline & & & (0.7) & (1.3) & (1.0) & $(0.8)$ & $(1.1)$ & (1.1) & (1.0) & (0.9) \\
\hline & \multirow[t]{2}{*}{$\mathrm{EC}$} & \multirow[t]{2}{*}{$\mu \mathrm{Scm}^{-1}$} & 67.7 & 52.3 & 99.1 & 135.5 & 217.3 & 217.3 & 131.7 & 127.6 \\
\hline & & & (44.2) & (47.4) & (9.6) & (63.2) & (73.8) & (73.8) & (21.4) & (24.4) \\
\hline & \multirow[t]{2}{*}{$\mathrm{SiO}_{2}$} & \multirow[t]{2}{*}{$\mathrm{mg}^{-1}$} & 2.8 & 1.8 & 8.8 & 11.3 & 16.2 & 16.2 & 21.7 & 22.9 \\
\hline & & & (3.9) & (3.3) & (5.1) & $(5.2)$ & (8.5) & $(8.5)$ & (3.9) & (5.8) \\
\hline \multirow[t]{4}{*}{ Anions } & \multirow[t]{2}{*}{$\mathrm{SO}_{4}^{2-}$} & \multirow[t]{2}{*}{$\mathrm{mg} \mathrm{l}^{-1}$} & 1.2 & 1.3 & 8.3 & 8.4 & 9.2 & 9.2 & 3.1 & 5.0 \\
\hline & & & (2.3) & (2.0) & (2.1) & (2.0) & (2.8) & (2.8) & (1.6) & (1.7) \\
\hline & \multirow[t]{2}{*}{$\mathrm{Cl}^{-}$} & \multirow[t]{2}{*}{$m g 1^{-1}$} & 0.52 & 1.0 & 4.16 & 6.4 & 1.2 & 1.2 & 5.6 & 5.6 \\
\hline & & & $(0.4)$ & (1.5) & (2.4) & (2.1) & (2.1) & $(2.1)$ & (3.6) & (3.4) \\
\hline \multirow[t]{8}{*}{ Cations } & \multirow[t]{2}{*}{$\mathrm{K}^{+}$} & \multirow[t]{2}{*}{$\operatorname{mg~} 1^{-1}$} & 1.0 & 1.5 & 1.1 & 1.3 & 3.3 & 3.3 & 2.1 & 3.2 \\
\hline & & & (0.9) & (1.0) & $(0.2)$ & $(0.2)$ & $(0.7)$ & $(0.7)$ & $(0.5)$ & (1.4) \\
\hline & \multirow[t]{2}{*}{$\mathrm{Mg}^{2+}$} & \multirow[t]{2}{*}{$\mathrm{mg} 1^{-1}$} & 0.3 & 0.5 & 1.9 & 2.5 & 2.9 & 2.9 & 3.2 & 3.4 \\
\hline & & & (0.4) & $(0.5)$ & $(0.4)$ & (0.4) & (1.3) & (1.3) & (1.0) & (1.1) \\
\hline & \multirow[t]{2}{*}{$\mathrm{Ca}^{2+}$} & \multirow[t]{2}{*}{$\mathrm{mg}^{-1}$} & 0.7 & 1.5 & 3.2 & 5.0 & 13.7 & 13.7 & 10.1 & 8.8 \\
\hline & & & (1.1) & $(0.9)$ & $(0.6)$ & $(0.7)$ & $(7.8)$ & (7.8) & $(2.5)$ & (2.6) \\
\hline & \multirow[t]{2}{*}{$\mathrm{Na}^{+}$} & \multirow[t]{2}{*}{$\mathrm{mg}^{-1}$} & - & 24.4 & - & 36.4 & 55.7 & 55.7 & 6.7 & 6.1 \\
\hline & & & & (14.1) & & $(9.4)$ & (11.3) & (11.3) & (1.1) & (0.9) \\
\hline
\end{tabular}

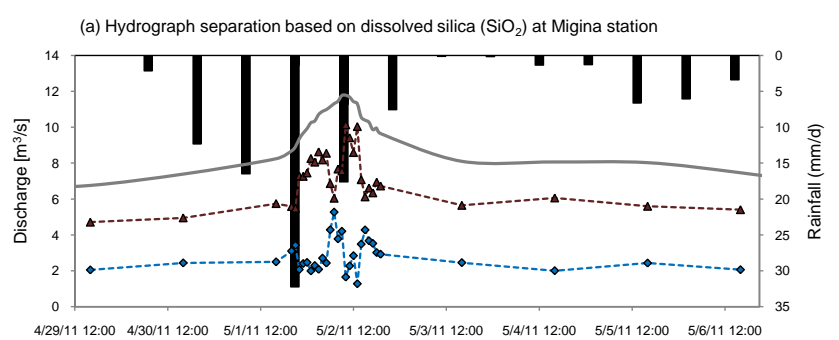

Date [hh:mm]

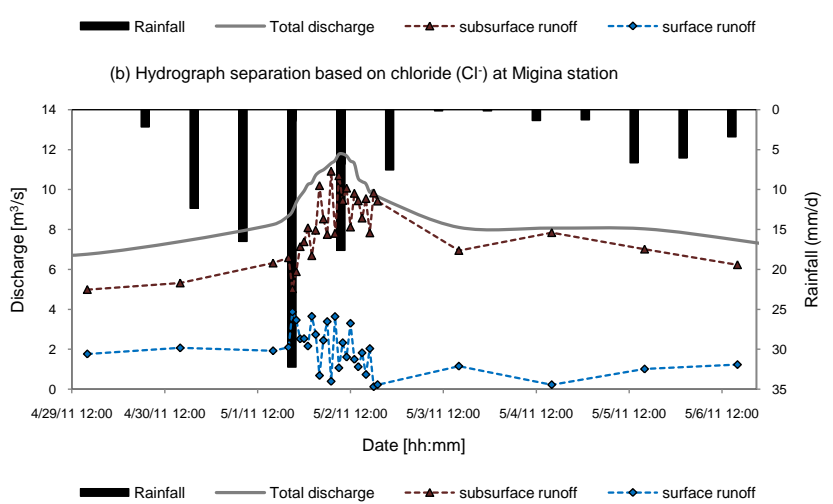

Fig. 5. Two-component hydrograph separations based on dissolved silica (a) and chloride (b) for subsurface and surface runoff for event M3 (see Fig. 2b) investigated from 29 April to 6 May 2011 at Migina station.
1-2 May 2010 at Kansi station. Subsurface runoff is dominating the surface runoff and contributes from 53 to $89 \%$ (about $75 \%$ on average) and from 56 to $99 \%$ (about $80 \%$ on average) using dissolved silica and chloride, respectively.

The results of the two-component hydrograph separations show that the majority of the flood was generated by subsurface runoff ( $80 \%)$, and the surface runoff contribution hardly varies during the event except some increase during the peak time. Similar to the event of May 2010 (Fig. 4), the maximum contribution of surface runoff during the event of May 2011 was observed at slightly different times for both tracers. Using dissolved silica for hydrograph separation, maximum surface runoff contribution was observed three hours before the peak runoff was reached (on 2 May 2011 at 07:00 LT) and contribute $47 \%$, while for chloride the maximum was observed two hours before the peak runoff was reached (on 2 May 2011 at 08:00 LT) and contribute up to $44 \%$. The falling limb is largely dominated by subsurface runoff.

\subsection{Results of isotopes tracer studies}

The assumptions of hydrograph separation (Sect. 3.3) have been investigated by comparing the temporal and spatial variability of the different tracers in rainwater and groundwater from springs and piezometers. In other words, the stability of end members was tested for the application of the threecomponent hydrograph separation technique. 
Table 4. Isotope concentrations observed at the Kansi sub-catchment and at the Migina catchment during the investigated research period (from 1 May 2009 to 31 June 2011); $n$ represents the number of samples; the entries in brackets represent the standard deviation values.

\begin{tabular}{|c|c|c|c|c|c|c|c|c|c|c|}
\hline & \multirow[b]{2}{*}{ Parameter } & \multirow[b]{2}{*}{ Unit } & \multicolumn{2}{|c|}{$\begin{array}{l}\text { Rainfall } \\
(n=145)\end{array}$} & \multicolumn{2}{|c|}{$\begin{array}{l}\text { Surface water } \\
\quad(n=173)\end{array}$} & \multicolumn{2}{|c|}{$\begin{array}{l}\text { Groundwater } \\
\quad(n=28)\end{array}$} & \multicolumn{2}{|c|}{$\begin{array}{l}\text { Springs } \\
(n=18)\end{array}$} \\
\hline & & & Kansi & Migina & Kansi & Migina & Kansi & Migina & Kansi & Migina \\
\hline Isotopes & $\delta^{2} \mathrm{H}$ & $(\%)$ & $-16.9(21.3)$ & $-7.8(16.6)$ & $-11.4(7.3)$ & $-3.5(6.7)$ & $-15.2(3.9)$ & $-15.2(3.9)$ & $-9.4(1.2)$ & $-8.8(2.3)$ \\
\hline & $\delta^{18} \mathrm{O}$ & $(\%)$ & $-4.3(3.6)$ & $-3.3(2.5)$ & $-3.0(1.0)$ & $-1.5(1.0)$ & $-3.7(0.6)$ & $-3.7(0.6)$ & $-3.1(0.3)$ & $-3.2(0.3)$ \\
\hline
\end{tabular}

Table 4 shows that the mean values of $\delta^{2} \mathrm{H}$ and $\delta^{18} \mathrm{O}$ in surface water runoff are $-11.4 \%$ and $-3.5 \%$ for $\delta^{2} \mathrm{H}$; and $-3.0 \%$ and $-1.5 \%$ for $\delta^{18} \mathrm{O}$. The values of these isotopes in rainfall water are $-16.9 \%$ and $-7.8 \%$ for $\delta^{2} \mathrm{H}$; and $-4.3 \%$ and $-3.3 \%$ for $\delta^{18} \mathrm{O}$. The mean values of $\delta^{2} \mathrm{H}$ and $\delta^{18} \mathrm{O}$ were also investigated in the same two catchments (Kansi and Migina) during the entire period of research (May 2009-June 2011) for groundwater during floods and low flows. Their values in shallow groundwater obtained from piezometers are $-15.2 \%$ and $-3.7 \%$, respectively. The mean values of $\delta^{2} \mathrm{H}$ and $\delta^{18} \mathrm{O}$ in water sampled from springs are $-9.4 \%$ and $-8.8 \%$ for $\delta^{2} \mathrm{H}$ and $-3.1 \%$ and $-3.2 \%$ for $\delta^{18} \mathrm{O}$.

End-member concentrations for deep and shallow groundwater were estimated based on data from piezometers located in the upper part of a hillslope and in a near stream location (Munyaneza et al., 2010). The end-member for rainfall samples was taken as an average of rainwater sampled at 4 automatic rainfall stations (see Fig. 1).

Figure 6 shows stable isotopes (oxygen-18 $\left({ }^{18} \mathrm{O}\right)$ and deuterium $\left.\left({ }^{2} \mathrm{H}\right)\right)$ in the water sampled in the Kansi sub-catchment and Migina catchment during the $2-y r$ study period. The slope of the constructed Local Meteoric Water Line for Butare (LMWL Butare, $\delta^{2} \mathrm{H}=7.72 \cdot \delta^{18} \mathrm{O}+16.12$

$\% o ; n=103)$ is close to the one of the Global Meteoric Water Line (GMWL, $\delta^{2} \mathrm{H}=8.13 \cdot \delta^{18} \mathrm{O}+10.8 \%$ ), but has a clearly higher intercept. However, it is obvious in Fig. 6 that the wet season rainfall is responsible for the light values of the groundwater and the baseflow. The isotopic composition of the rainfall is clearly different in the dry and wet season, and the wet season rainfall signature dominates the other water balance components (surface and subsurface water). Interestingly, the isotope values of the observed springs are not influenced by dry season rainfall values, as they all plot below the LMWL, show lighter isotope values than the amount weighted rainfall values of the wet season rainfall input. Thus, it can be concluded that the perennial springs in the area are recharged exclusively during the wet season.

The figure shows also that most of the stables isotopes of groundwater and spring water in the catchments are lighter than those of the stream waters and they plot even below the LMWL. This means probably that infiltrated water is affected by evaporation before reaching the groundwater system (temporary storage in soil zone). Similar results were

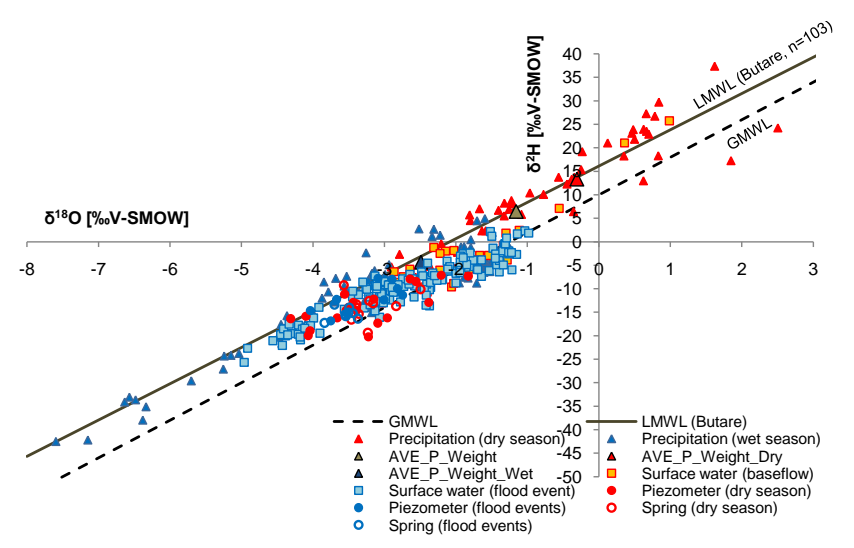

Fig. 6. Stable isotope compositions of rainfall, surface water, springs, shallow groundwater, and amount weighted rainfall for dry and wet seasons. GMWL: $\delta^{2} \mathrm{H}=8.13 \delta^{18} \mathrm{O}+10.8$ (Source: Clark and Fritz, 1997). GMWL is the Global Meteoric Water Line; LMWL is the Local Meteoric Water Line for Butare; AVE_P_Weight means the average weight rainfall concentration for water sampled during wet and dry seasons; AVE_P_Weight_Dry means the average weight rainfall concentration for water sampled in summer season; and AVE_P_Weight_Wet represents the average weight rainfall concentration for water sampled during in rainy season.

found, for instance, by Kabeya et al. (2007) in a forested watershed in Kampong Thom, Cambodia.

A three-component hydrograph separation was applied in this study by using dissolved silica and deuterium for the event of 1-2 May 2010 at Kansi station (Fig. 7) and using dissolved silica and oxygen-18 as tracers for the event of 29 April 2011 to 6 May 2011 at Migina station (Fig. 9).

Figure 7 shows the results of the three-component separation method using dissolved silica and deuterium as tracers for the investigated event of 2 May 2010 at Kansi station. The results are comparable to the results obtained from the two-component hydrograph separations (see Sect 4.2). Preevent water (deep and shallow groundwater, $Q_{\mathrm{dgw}}+Q_{\mathrm{sgw}}$ ) is dominating the discharge generation in this event and is contributing 38-98\% (about $80 \%$ on average) to the total discharge $\left(Q_{\mathrm{t}}\right)$. Event water (direct runoff, $\left.Q_{\text {dir }}\right)$ dominates during few hours (on 1 May 2010 at 17:00 LT) during the rising limb and contributes then about $60 \%$. The peak flow is also dominated by pre-event water $(76.7 \%)$ and occurred on 


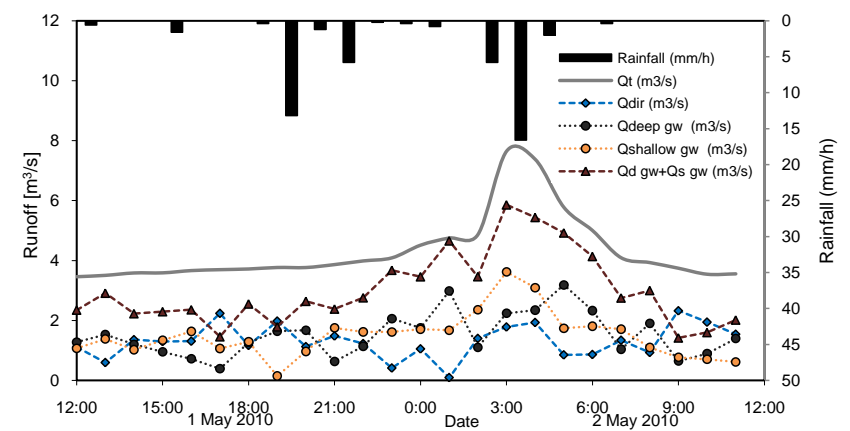

Fig. 7. Results of the three-component separation using dissolved silica and deuterium as tracers for event K6 (see Fig. 2a) investigated from 1 May 2010 at 12:00 to 2 May 2010 at 11:00 at Kansi station. $Q_{\mathrm{dgw}}+Q_{\mathrm{sgw}}$ is the sum of deep and shallow groundwater components.

2 May 2010 at 03:00 LT. Note that the shallow groundwater has been sampled in the valley, and the deep groundwater has been observed at perennial springs with constant discharge and hydrochemical characteristics.

The rainfall was sampled intensively during the event of 29 April 2011 to 6 May 2011 with a high temporal resolution of rainfall samples for isotope analysis (Fig. 8). The $\delta^{18} \mathrm{O}$ value of the rainfall event ranges between $-1.93 \%$ to $-1.24 \%$ and the mean bulk rainfall $\delta^{18} \mathrm{O}$ value for the whole event is equal to $-1.52 \%$ o (see Fig. 8). The incremental weighting approach based on rainfall amount was applied, Eq. (5), as recommended by McDonnell et al. (1990), but due to the observed very low temporal variations of isotopes in rainfall, the effect of this method is limited.

Figure 8 shows the $\delta^{18} \mathrm{O}$ values of rainfall calculated using the incremental weighting approach, Eq. (5), and the mean values fluctuate between $-1.71 \%$ o to $-1.48 \%$ (Fig. 8a). For the three-component hydrograph separation of this event the isotopic signature of rainwater (incremental means) was considered (Fig. 9). Therefore, the end-member value for rainfall is not constant, but varied over time.

Figure 9 shows the results of the three-component separation using dissolved silica and oxygen-18 as tracers. During this event, pre-event water (deep and shallow groundwater, $\left.Q_{\mathrm{dgw}}+Q_{\mathrm{sgw}}\right)$ was chiefly responsible for stream generation and contributed to the total discharge 10-98\% (about $60 \%$ on average). Maximum surface runoff generation occurred at the hour of peak discharge (on 2 May 2011 at 10:00 LT) and event water (direct runoff, $Q_{\text {dir }}$ ) contributed for a short period about $70 \%$. Thus, the peak is dominated by direct runoff but the total discharge $\left(Q_{t}\right)$ is dominated by subsurface water similar to the event of May 2010. However, the results found for this separation are somewhat different from previous results, but the assumptions of the methods are not fully met and cause some uncertainty of the method (Sect. 3.3). Unfortunately, there is no independent experimental data that can prove the stormflow composition during peak flow.
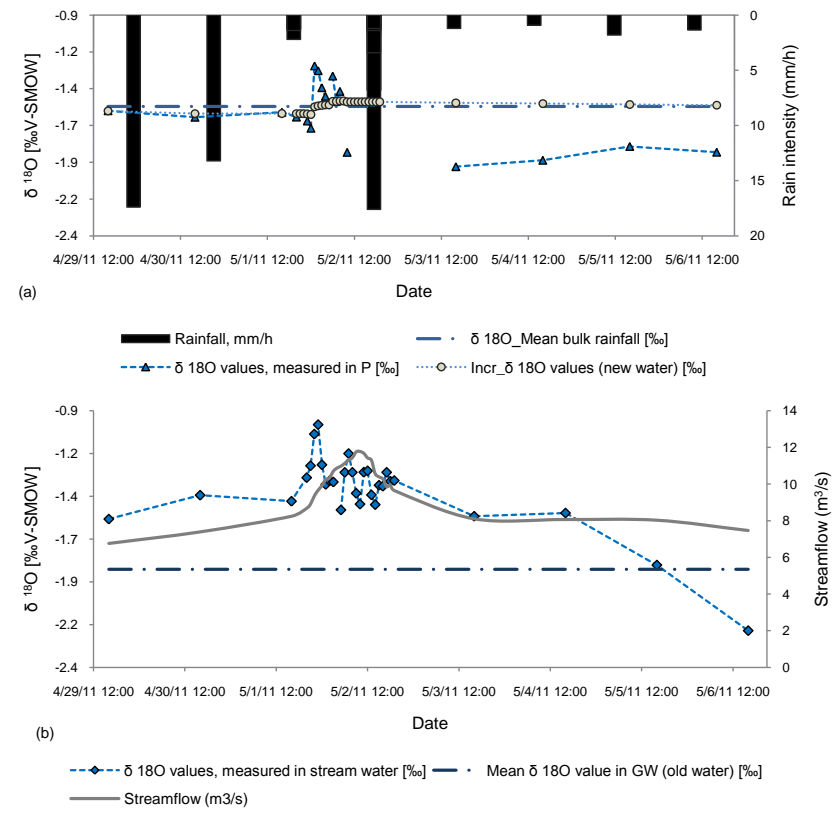

Fig. 8. Hourly rainfall and variations of $\delta^{18} \mathrm{O}$ in rainfall (a), discharge and variations of $\delta^{18} \mathrm{O}$ in the stream water (b) during 29 April 2011 to 6 May 2011 storm event.

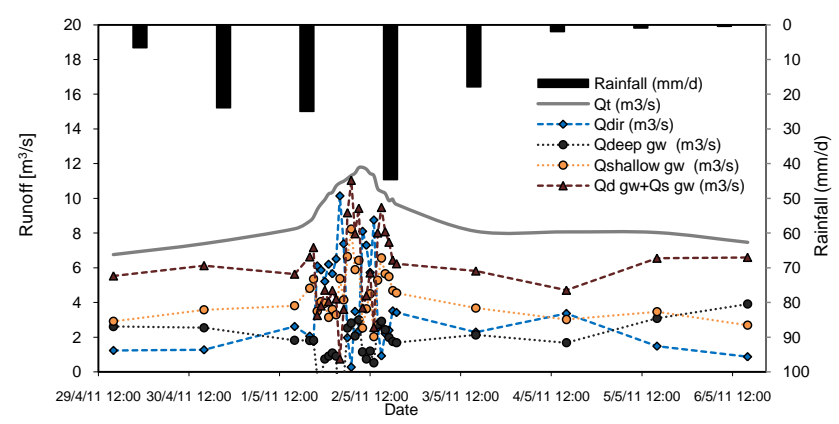

Fig. 9. Results of the three-component separation using dissolved silica and oxygen-18 as tracers for event M3 (see Fig. 2b) investigated from 29 April 2011 to 6 May 2011 at Migina station. $Q_{\mathrm{dgw}}+Q_{\mathrm{sgw}}$ is the sum of deep and shallow groundwater components.

\section{Discussion}

\subsection{Rainfall influence on runoff generation}

Rainfall and discharge data used in this research were collected over two years (May 2009-June 2011) and the rainy season "Itumba" was investigated in further detail. Low runoff coefficients for different events were determined, ranging between 16.7 and $44.5 \%$ for Kansi sub-catchment (Table 1) and between 31.5 and $44.4 \%$ for Migina catchment (Table 2). This indicates that the stormflow reaches the stream largely through the soil by subsurface runoff due to high infiltration rates. This type of runoff generation 
was supported by observed chemical concentrations in surface water, which are closer to the concentrations of water sampled from springs and piezometers during flood events (Table 3).

The high infiltration in the Migina catchment can be explained by a very high hydraulic conductivity of the soil as observed by Van den Berg and Bolt (2010) using double ring infiltrometer tests in the same catchment; the infiltration rate varied between $208 \mathrm{~mm} \mathrm{~h}^{-1}$ to $1250 \mathrm{~mm} \mathrm{~h}^{-1}$. The tests were conducted at locations where the land is used for agriculture. The rainfall intensities which are less than $17.6 \mathrm{~mm} \mathrm{~h}^{-1}$ are much lower than the infiltration rates (see Tables 1 and 2). Van den Berg and Bolt (2010) also analyzed maximum soil water content in the soil laboratory and found that the soil can hold up to $60-70 \%$ of water. This forms an important shallow subsurface water storage, which makes agriculture possible even in dry periods. Hence, this can lead to a shallow subsurface runoff component contributing to the total streamflow if the storage threshold is exceeded.

Munyaneza et al. (2011) found the long-term average runoff coefficient of Migina catchment to be $25 \%$, which is in the range of the results found in this study. In the same study, they also found that the Migina catchment is dominated by agricultural land use $(92.5 \%)$. The range of runoff coefficients found in this current study (16.7-44.5\%) agrees with the range for agricultural dominated catchments found, e.g. by Larsen et al. (2007). This gives a hint towards the importance of infiltration and subsurface flow generation during events. Runoff generation obviously depends on other factors such as the degree of slope, soil type, vegetation cover, antecedent soil moisture, rainfall intensity and duration. The runoff coefficient ranges usually between $1 \%$ and $50 \%$ in cultivated catchments (FAO, 2006). Marchi et al. (2010) did a study for extreme flash floods in Europe and found that the runoff coefficients of the studied flash floods are usually rather low with a mean value of 0.35 . Moderate differences in runoff coefficient are observed between the studied climatic regions, with higher values in the Mediterranean region. Ley et al. (2011) found that the annual mean runoff coefficients in nested catchments of Rhineland-Palatinate, Germany, may range from $2 \%$ to $15 \%$ in the summer period, while during winter time they range from $5 \%$ to $56 \%$. The high runoff coefficients observed in Germany in winter are due to snow influence and can be the same as the case in the Rwanda areas but due to heavy rainfall observed during the events (see Fig. 2). However, the current research was done during the rainy season "Itumba". Therefore, it can be concluded from the rainfall-runoff response analysis that runoff generation at the Kansi and Migina catchments is dominated by subsurface flows as highly supported by the hydrograph separation (see Sect. 4.3).

\subsection{Quantification of runoff components and processes in a meso-scale catchment}

Streamflow hydrograph separations were found to be possible using dissolved silica and chloride as tracers due to their variations in concentrations observed during two investigated flood events. However, the remaining analyzed chemical components $\left(\mathrm{SO}_{4}^{2-}, \mathrm{Na}^{+}, \mathrm{K}^{+}, \mathrm{Mg}^{2+}\right.$, and $\left.\mathrm{Ca}^{2+}\right)$ could not be used for hydrograph separations, because they showed constant concentrations in the streamflow during the events (likely due to non-conservative transport behavior) and did not provide additional insights. Their concentrations in surface runoff and groundwater were too similar to do reliable hydrograph separations. Richey et al. (1998) used the same method and found that chemical tracers like $\mathrm{SiO}_{2}$ and $\mathrm{Cl}^{-}$may be non-conservative in subsurface water on longer timescales, but they can be assumed to behave conservatively on the time scale of a single runoff event. These findings indicate that spatial variability in the components may be more important when determining the precision of the pre-event water fraction. In fact, direct runoff or event water data generated by the selected four tracers in this study offer insights into how the catchments respond hydrologically and were used to develop a perceptual model of how catchment generates runoff.

The two-component hydrograph separation model using dissolved silica and chloride led to a high amount of subsurface contribution (up to $80 \%$ ) in both catchments. For both investigated events at Kansi and Migina station, the direct runoff component did not exceed 33.7 and $28.7 \%$ of the total event runoff, respectively. The observed dominance of subsurface runoff in these two storm events was probably facilitated by the wet conditions during the rainy season (Fig. 2).

The three-components runoff separation model using dissolved silica and deuterium, and using dissolved silica and oxygen-18, shows somewhat different results, but both confirmed the high contribution of pre-event runoff components (about $80 \%$ using $\mathrm{SiO}_{2}$ and ${ }^{2} \mathrm{H}$; and about $60 \%$ using $\mathrm{SiO}_{2}$ and ${ }^{18} \mathrm{O}$ ). The observed differences could be due to the consideration of spatial and temporal variability of oxygen-18 concentrations in rainfall during the event of May 2011 where rainwater was sampled. For the two investigated events (Figs. 7 and 9), the mean value of the new water component is 31.9 and $38.8 \%$ of the total runoff for event of May 2010 and 2011, respectively. The dominance of subsurface water found using three-component separations confirms the findings of temporally highly variable but in total relatively small contribution of surface runoff.

The observed dominance of old water (up to $80 \%$ ) in the Migina catchment confirms the finding of van den Berg and Bolt (2010) in their study during the dry season. They found that the locations of shallow groundwater in the Migina catchment are between $0.2 \mathrm{~m}$ and $2 \mathrm{~m}$, which enables infiltrated rain to reach the groundwater quickly and contribute to subsurface stormflow and later to baseflow. This behavior 
was explained e.g. by McDonnell et al. (1990) by the fact that the rapid flow of new rainwater during downward and lateral flow in macropores interacts with the soil matrix. The findings of this current paper were also supported by results from several other hydrochemical (and isotopic) studies that found old water and subsurface flow to be the major (more than $50 \%$ ) component of stormflow in different hydro-climatic rainfall (e.g. Sklash et al., 1976; Sklash and Farvolden, 1979; Kennedy et al., 1986; Rice and Hornberger, 1998; Didszun and Uhlenbrook, 2008; Hrachowitz et al., 2011). Our results are in line with Mul et al. (2008) who did a similar study in a semi-arid area using hydrochemical tracers for hydrograph separation and found that over $95 \%$ of the discharge could be attributed to sub-surface runoff during smaller events, while the remainder was due to faster surface runoff processes. Hrachowitz et al. (2011) carried out a study in another semi-arid catchment using hydrometric observation and found that the use of multiple tracers allowed estimating uncertainties in hydrograph separations occurring from the use of different tracers. Applying hydrograph separation methods to larger catchments $>40 \mathrm{~km}^{2}$ often leads to only qualitative results (Uhlenbrook and Hoeg, 2003; Didszun and Uhlenbrook, 2008). However, hydrograph separation in Migina meso-scale catchment helped to gain further insights in runoff process understanding. The runoff components and processes in a meso-scale catchment for two flood events could be estimated and led to a perceptual understanding of the catchment functioning.

\section{Conclusions}

The applicability of tracer methods in conjunction with hydrometric measurements for identifying dominant runoff generation processes in the meso-scale Migina catchment was tested. The two- and three-components hydrograph separation models using hydrochemical (dissolved silica and chloride) and isotope (deuterium and oxygen-18) tracers show that intensive water sampling (hourly) during events is essential. The whole rising limb, peak and recession limb need to be captured completely for the event in order to gain more understanding of runoff generation processes. In addition, different geographic sources of runoff need to be observed before, during and after the events. The outcomes of such an investigation are essential for understanding the catchment functioning and the sustainable water resources management and agricultural development to meet the high water demands related to the rapid Rwandan population increase.

The results of this study demonstrate the importance of subsurface flows for streamflow generation in the study area. It shows the value of detailed hydrological data collection over two whole rainy seasons using different tracers and hydrometric observation to understand dominant hydrological processes. Furthermore, it demonstrates the significance of considering spatial and temporal variations of rainfall in the hydrograph separations (Figs. 8 and 9); this is of greater importance in meso-scale catchments than in small headwaters. Oxygen-18 $\left({ }^{18} \mathrm{O}\right)$ and deuterium $\left({ }^{2} \mathrm{H}\right)$ were found to be suitable tracers to detect event vs. pre-event water sources. Additionally, it was found that groundwater has two different origins: one source originates from a near stream location in the valleys (shallow groundwater) and the other source is deep groundwater sampled at piezometers and springs located in the upper part of the hillslopes (Sect. 4.3). The significant groundwater recharge during the wet seasons led to the perennial river system observed in the catchment. The isotope analysis shows that all runoff components including baseflow are dependent on wet season rainfall.

Acknowledgements. The work reported here was undertaken as part of a joint project carried out by the National University of Rwanda (NUR), Butare, Rwanda, and UNESCO-IHE Institute for Water Education, Delft, The Netherlands. The authors would like to recognize the support of National University of Rwanda, Nile Basin Capacity Building Network (NBCBN), UNESCO-IHE and the $\mathrm{PhD}$ research fellowship for the first author and the contribution to the research costs provided by the Government of The Netherlands. Furthermore, the inputs during field work of the MSc research students H. Van den Berg and R. Bolt (VU Amsterdam, The Netherlands are gratefully acknowledged. The authors thank also F. Kruis and F. Battes (UNESCO-IHE, Delft, The Netherlands) for $\mathrm{Cl}^{-},{ }^{2} \mathrm{H}$ and ${ }^{18} \mathrm{O}$ analysis as well as M. Birori and D. Gashugi (NUR, Butare, Rwanda) for $\mathrm{SiO}_{2}$ analysis.

Edited by: E. Zehe

\section{References}

Blume, T., Zehe, E., and Bronstert, A.: Rainfall-runoff response, event-based runoff coefficients and hydrograph separation, Hydrolog. Sci. J., 52, 843-862, 2007.

Burch, G. J., Bath, R. K., Moore, I. D., and O'Loughlin, E. M.: Comparative hydrological behaviour of forested and cleared catchments in southeastern Australia, J. Hydrol., 90, 19-42, 1987.

Burns, D. A.: Stormflow-hydrograph separation based on isotopes: the thrill is gone-what's next?, Hydrol. Process., 16, 1515-1517, 2002.

Buttle, J. M.: Isotope hydrograph separations and rapid delivery of pre-event water from drainage basins, Progr. Phys. Geogr., 18, 16-41, 1994.

Clark, I. and Fritz, P.: Environmental Isotopes in Hydrology, CRC Press, New York, USA, 1355-1356, 1997.

Cras, A., Marc, V., and Travi, Y.: Hydrological behaviour of subMediterranean alpine headwater streams in a badlands environment, J. Hydrol., 339, 130-144, 2007.

Didszun, J. and Uhlenbrook, S.: Scaling of dominant runoff generation processes: Nested catchments approach using multiple tracers, Water Resour. Res., 44, W02410, doi:10.1029/2006WR005242, 2008. 
FAO: Système d'information de la FAO sur l'eau et l'agriculture, Information system for water and agriculture, Food and Agriculture Organization (FAO) of the United Nation, Rome, Italy, 2005.

FAO: Design model for catchment: Cultivated area ratio. Food and Agriculture Organization (FAO) of the United Nation, Natural Resources Management and Environment Department, Rome, Italy, 2006.

Hrachowitz, M., Bohte, R., Mul, M. L., Bogaard, T. A., Savenije, H. H. G., and Uhlenbrook, S.: On the value of combined event runoff and tracer analysis to improve understanding of catchment functioning in a data-scarce semi-arid area, Hydrol. Earth Syst. Sci., 15, 2007-2024, doi:10.5194/hess-15-2007-2011, 2011.

Iroumé, A., Huber, A., and Schulz, K.: Summer flows in experimental catchments with different forest covers, Chile, J. Hydrol., 300, 300-313, 2005.

James, A. L. and Roulet, N. T.: Antecedent moisture conditions and catchment morphology as controls on spatial patterns of runoff generation in small forest catchments, J. Hydrol., 377, 351-366, 2009.

Kabeya, N., Shimizu, A., Chann, S., Tsuboyama, Y., Nobuhiro, T., Keth, N., and Tamai, K.: Stable isotope studies of rainfall and stream water in forest watershed in Kampong Thom, Cambodia, Forest Environ. Mekong River Basin, 1, 125-134, doi:10.1007/978-4-431-46503-4_11, 2007.

Kennedy, V. C., Kendall, C., Zelleweger, G. W., Wyerman, T. A., and Avanzino, R. J.: Determination of the components of stormflow using water chemistry and environmental isotopes, Mattole River basin, California, J. Hydrol., 84, 107-140, 1986.

Ladouche, B., Probst, A., Viville, D., Idir, S., Baque, D., Loubet, M., Probst, L. J., and Bariac, T.: Hydrograph separation using isotopic, chemical and hydrological approaches (Strengbach catchment, France), J. Hydrol., 242, 255-274, 2001.

Larsen, I. J., MacDonald, L. H., Brown, E., Rough, D., Welsh, M. J., Pietraszek, J. H., Libohova, Z., and Schaffrath, K.: Causes of post-fire runoff and erosion: the roles of soil water repellency, surface cover, and soil sealing, Department of Forest, Rangeland, and Watershed Stewardship, Colorado State University, Fort Collins, Colorado, 2007.

Ley, R., Casper, M. C., Hellebrand, H., and Merz, R.: Catchment classification by runoff behaviour with self-organizing maps (SOM), Hydrol. Earth Syst. Sci., 15, 2947-2962, doi:10.5194/hess-15-2947-2011, 2011.

Marc, V., Didon-Lescot, J. F., and Michael, C.: Investigation of the hydrological processes using chemical and isotopic tracers in a small Mediterranean forested catchment during autumn recharge, J. Hydrol., 247, 215-229, 2011.

Marchi, L., Borga, M., Preciso, E., and Gaume, E.: Characterisation of selected extreme flash floods in Europe and implications for flood risk management, J. Hydrol., 394, 118-133, 2010.

McDonnell, J. J., Bonell, M., Stewart, K. M., and Pearce, J. A.: Deuterium Variations in Storm Rainfall: Implications for Stream Hydrograph Separation, Water Resour. Res., 26, 455-458, 1990.

MINIPLAN: Recensement Général de la Population et de l'Habitat, Kigali, Rwanda, 2002.

Moeyersons, J.: Ravine formation on steep slopes: forward versus regressive erosion, Some case studies from Rwanda, Catena, 18, 309-324, 1991.
Munyaneza, O., Uhlenbrook, S., Wenninger, J., van den Berg, H., Bolt, H. R., Wali, G. U., and Maskey, S.: Setup of a Hydrological Instrumentation Network in a Meso-Scale Catchment- the case of the Migina Catchment, Southern Rwanda, Nile Water Sci. Eng. J., 3, 61-70, 2010.

Munyaneza, O., Ufiteyezu, F., Wali, U. G., and Uhlenbrook, S.: A simple Method to Predict River Flows in the Agricultural Migina Catchment in Rwanda, Nile Water Sci. Eng. J., 4, 24-36, 2011.

Mul, M. L.: Understanding hydrological processes in an ungauged catchment in Sub-Saharan Africa, PhD thesis, ISBN: 978-0-41554956-1, Taylor \& Francis Group, UNESCO-IHE Institute for Water Education, Delft, The Netherlands, 2009.

Mul, M. L., Mutiibwa, K. R., Uhlenbrook, S., and Savenije, H. G. H.: Hydrograph separation using hydrochemical tracers in the Makanya catchment, Tanzania, Phys. Chem. Earth, 33, 151-156, 2008.

Nahayo, D.: Feasible Solutions for an Improved Watershed Management in Sloping Areas, Rwanda, Proceedings of Water and Land session, 9th WATERNET/WARFSA/GWP-SA Symposium, Johannesburg, South Africa, 29-31 October 2008.

Nahayo, D., Wali, U. G., and Anyemedu, F. O. K.: Irrigation practices and water conservation opportunities in Migina marshlands, Int. J. Ecol. Develop., 16, 100-112, 2010.

NELSAP: Natural Resources Management and Development, NELSAP Rwanda, Visited in November 2008, available at: http: //web.worldbank.org/Rwanda (last access: 25 November 2008), 2007.

Pinder, G. F. and Jones, J. F.: Determination of the groundwater component of peak discharge from the chemistry of total runoff, Water Resour. Res., 5, 438-445, 1969.

Rice, K. C. and Hornberger, G. M.: Comparison of hydrochemical tracers to estimate source contributions to peak flow in a small, headwater catchment, Water Resour. Res., 34, 1755-1766, 1998.

Richey, G. D., McDonnell, J. J., Erbe, W. M., and Hurd, M. T.: Hydrograph separation based on chemical and isotopic concentrations: a critical appraisal of published studies from New Zealand, North America and Europe, J. Hydrol., 37, 95-111, 1998.

S. H. E. R. ingenieurs-conseils: Etudes de faisabilite, Marais de la Migina, Rapport provisoire phase 2, Ministry of Agriculture, Kigali, Rwanda, 2003.

Sklash, M. G. and Farvolden, R. N.: The role of groundwater in storm runoff, J. Hydrol., 43, 45-65, 1979.

Sklash, M. G., Farvolden, R. N., and Fritz, P.: A conceptual model of watershed response to rainfall, developed through the use of oxygen-18 as a natural tracer, Can. J. Earth Sci., 13, 271-283, 1976.

Sklash, M. G., Stewart, M. K., and Pearce, A. J.: Storm runoff generation in humid head-water catchments, 2. A case study of hillslope and low order stream response, Water Resour. Res., 22, 1273-1282, 1986.

Spieksma, J. F. M.: Changes in the Discharge Pattern of a Cutover Raised bog During Rewetting, Hydrol. Process., 13, 1233-1246, 1999.

Uhlenbrook, S. and Hoeg S.: Quantifying uncertainties in tracerbased hydrograph separations - A case study for two, three and five component hydrograph separations in a mountainous catchment, Hydrol. Process., 17, 431-453, 2003. 
Uhlenbrook, S., Frey, M., Leibundgut, C., and Maloszewski, P.: Hydrograph separations in a mesoscale mountainous basin at event and seasonal timescales, Water Resour. Res., 38, 1096-1110, doi:10.1029/2001wr000938, 2002.

Van den Berg, W. H. and Bolt, H. R.: Catchment analysis in the Migina marshlands, southern Rwanda, MSc Thesis in Hydrology and Geo-environmental Sciences, Vriije University Amsterdam, UNESCO-IHE Institute for Water Education, Delft, The Netherlands and National University of Rwanda, Butare, 148 pp., 2010.
Wels, C., Cornett, R. J., and Lazerte, B. D.: Hydrograph separation: a comparison of geochemical and isotopic tracers, J. Hydrol., 122, 253-274, 1991.

Wenninger, J., Uhlenbrook, S., Lorentz, S., and Leibundgut, C.: Identification of runoff generation processes using combined hydrometric, tracer and geophysical methods in a headwater catchment in South Africa, J. Hydrol. Sci., 53, 65-80, 2008. 